Review

\title{
Environmental and Anthropogenic Factors Influencing Salamanders in Riparian Forests: A Review
}

\author{
Hannah L. Clipp and James T. Anderson * \\ Environmental Research Center and Division of Forestry and Natural Resources, West Virginia \\ University, P.O. Box 6125, Morgantown, WV 26506, USA; E-Mail: hannah.clipp@gmail.com \\ * Author to whom correspondence should be addressed; E-Mail: jim.anderson@mail.wvu.edu; \\ Tel.: +1-304-293-3825; Fax: +1-304-293-2441.
}

External Editor: Deanna H. Olson

Received: 7 October 2014; in revised form: 6 November 2014 / Accepted: 6 November 2014 / Published: 13 November 2014

\begin{abstract}
Salamanders and riparian forests are intimately interconnected. Salamanders are integral to ecosystem functions, contributing to vertebrate biomass and complex food webs in riparian forests. In turn, these forests are critical ecosystems that perform many environmental services, facilitate high biodiversity and species richness, and provide habitat to salamander populations. Due to the global decline of amphibians, it is important to understand, as thoroughly and holistically as possible, the roles of environmental parameters and the impact of human activities on salamander abundance and diversity in riparian forests. To determine the population responses of salamanders to a variety of environmental factors and anthropogenic activities, we conducted a review of published literature that compared salamander abundance and diversity, and then summarized and synthesized the data into general patterns. We identify stream quality, leaf litter and woody debris, riparian buffer width, and soil characteristics as major environmental factors influencing salamander populations in riparian forests, describe and explain salamander responses to those factors, and discuss the effects of anthropogenic activities such as timber harvest, prescribed fires, urbanization, road construction, and habitat fragmentation. This review can assist land and natural resource managers in anticipating the consequences of human activities and preparing strategic conservation plans.
\end{abstract}


Keywords: abundance; amphibian; coarse woody debris; forest management; fragmentation; microhabitat; riparian forest; salamanders; stream buffer; timber harvest

\section{Introduction}

Riparian forests are critical ecosystems that are found adjacent to water bodies such as streams and function as the transition zone between terrestrial and aquatic areas. They play an important role in forest landscapes, and forested riparian strips can be used by landowners to reduce water pollution from agricultural practices [1,2] and by forest managers to enhance ecosystem function [3,4]. Riparian forests perform many important environmental services, such as providing core habitat for a diverse variety of organisms, controlling in-stream processes, moderating shade and water temperature, acting as corridors for dispersal and foraging, supporting high soil moisture, and modifying the amount of nutrient export from watersheds $[3,5,6]$. For instance, riparian forest buffer systems have been used to provide effective control of nonpoint source pollution in certain agricultural watersheds, improving water quality by removing nutrients from runoff and reducing sediment transport [7-9]. In addition, riparian zones facilitate the exchange of nutrients between forest and freshwater ecosystems through litter and terrestrial/aquatic insect input and emergence [10,11]. Furthermore, riparian forests are important for recreation, forest products, hunting, fishing, and other human values.

Riparian zones are utilized by a variety of wildlife, particularly semi-aquatic and riparian specialist species, and studies indicate that these zones facilitate high biodiversity and species richness. Species diversity stems from environmental variation caused by upland influences on the stream, geomorphic channel processes, flood regimes, climate shifts at different altitudes, and the diversity of physical conditions found within the transition zone between terrestrial and aquatic ecosystems [12,13]. For instance, the landscape composition (e.g., presence of forests $v s$. impervious surfaces) of upland regions can enhance or degrade water quality by influencing the amount of nutrient and sediment runoff $[5,14,15]$. Similarly, factors such as stream size, local geomorphology, and hydrologic regime can determine the width of a riparian zone and the richness of its associated plant community, which in turn influences the presence of other riparian and stream biota [12,16]. Studies in Sweden [16], Finland [17], Amazonia [18,19], France [20,21], and the United States [22] reflect high biodiversity of vascular plants in riparian areas. For instance, Amazonian riparian forests contain over a thousand species [23], and 900 taxa of riparian vegetation were found along a river corridor in France [20]. Furthermore, Raedeke [24] reports that nearly $70 \%$ of vertebrate species within the surrounding region will use riparian corridors during their lifetime. In addition to microhabitat diversity, riparian habitats increase regional species richness by supporting different species than adjacent upland habitats (i.e., habitats not flanking a riverine, lacustrine, or palustrine system) [13]. For instance, in the Pacific Northwest, piscivorous birds and mammals such as kingfishers (Ceryle alcyon), mergansers (Mergus spp., Lophodytes cucullatus), herons (Ardea spp.), and mink (Neovison vison) are often associated with riparian areas [25]. Some species of invertebrates, such as the mayfly Paraleptophlebia gergalis, the stonefly Soyedina interrupta, and certain craneflies and crayfish, may even be unique or uniquely adapted to 
headwater riparian areas [26,27], and amphibians such as salamanders can be particularly diverse and abundant within riparian systems [28-30].

Salamanders play an essential ecological role in riparian forests. They function as both carnivores and prey species, and they can compose a significant proportion of forest vertebrate biomass [29,31,32]. For instance, Burton and Likens [29] found that salamander biomass $\left(1.77 \mathrm{~kg} \cdot \mathrm{ha}^{-1}\right)$ in the Hubbard Brook Experimental Forest, New Hampshire, was approximately two times greater than the biomass of birds and equal to the biomass of mice and shrews. Similarly, Peterman et al. [32] estimated a salamander community biomass $\left(99.30 \mathrm{~kg} \cdot \mathrm{ha}^{-1}\right.$ for adult black-bellied salamanders (Desmognathus quadramaculatus); $143.8 \mathrm{~kg} \cdot \mathrm{ha}^{-1}$ for the entire stream salamander community) that was greater than that of a Virginia headwater fish community, and they suggest that the biomass of southern Appalachian stream salamanders also exceeded the biomasses of birds and small mammals. Salamanders are also important components within the energy flow and nutrient cycling of a forest. Their terrestrial, aquatic, and fossorial movements connect energy and matter between landscape elements as well as influence soil dynamics [33-35]. Salamanders are poikilothermic, convert ingested energy efficiently (60\%) into their own biomass, and are high in protein content, making them a source of high-quality energy for prospective predators [35]. As mid-level consumers themselves, salamanders influence the species diversity of lower trophic levels as well as the process of detritus-litter decomposition on the forest floor [33,34].

In addition, salamanders can be used as cost-effective indicator species by providing readily quantifiable metrics of ecosystem health, function, and integrity in forest environments [33,36,37]. Due to their highly permeable skin and dependency on multiple habitat types throughout their life cycles, salamanders are physiologically linked to microclimatic and environmental processes. As such, they are sensitive to natural and anthropogenic disturbance and can be used to assess fine-scale processes, serving as an important resource in monitoring long-term forest health [36]. They can also be used as indicators to monitor stream health and water quality. For instance, due to the life history, physiology, abundance, ubiquity, and responses of stream salamanders to multiple stressors, the Maryland Department of Natural Resources has concluded that they are good indicators of environmental health and created a stream salamander index of biotic integrity [37]. Similarly, native stream salamander densities were used as indicators of stream ecosystem stress in California [38], larval salamanders can be used as indicators of hydrologic permanence in forested headwater streams [39], and an index of biotic integrity for macroinvertebrates and salamanders was used to assess aquatic communities in primary headwater habitat streams in Ohio [40].

However, amphibians across the world are in decline, and salamanders are no exception. There are more than two hundred salamander taxa identified in the United States, and at least $29 \%$ are ranked by NatureServe as "imperiled or critically imperiled" in a portion of their ranges (roughly equivalent to the IUCN's Red List designation of "critically endangered," "endangered," and "vulnerable") [33]. Potential and established reasons for their decline include forest fragmentation and habitat alteration [41], land use disturbance and urbanization [42,43], epidemic disease [44,45], climate change [44,46], pollutants/contaminants [44,45], acidic deposition [47,48], harvest/predation [45,49], and interactions between these factors [50]. To direct conservation and management efforts in the United States and worldwide, it is important to understand, as thoroughly and holistically as possible, the roles of environmental parameters and the impacts of human activities on salamander abundance and diversity.

Salamanders have complex life cycles, and they interact with biotic and abiotic variables within the environment at multiple spatial and temporal scales [51,52]. It is imperative to account for different levels 
of biological organization (e.g., genetics, individual behavior, population and community responses) in the context of ecosystem influences and land use [53]. For instance, Cecala [54] found that canopy gaps from small land-use changes altered the behavior and restricted the movement of stream salamanders in the Appalachian Mountains. In addition, spring salamanders (Gyrinophilus porphyriticus), dusky salamanders (Desmognathus fuscus), and seal salamanders (D. monticola) exhibit a general behavioral tendency to move upstream, possibly due to evolutionary dispersal traits [55,56]. The ideal approach to address conservation questions and management issues would reflect this complexity and multidimensionality in salamander ecology by considering microhabitat-, stream/stand-, and landscape-level factors and by monitoring changes and impacts over time (e.g., one vs. five vs. ten years post-disturbance).

To determine the population responses of salamanders in the United States to a variety of environmental and anthropogenic factors, we conducted a review of published literature that compared salamander abundance and diversity, and then summarized and synthesized the data into general patterns. The goals of this review were to: (1) identify the environmental factors influencing salamander populations in North American riparian forests; (2) describe and explain salamander responses to those factors; and (3) examine the effects of major anthropogenic activities, including timber harvest, prescribed fires, urbanization, road construction, and habitat fragmentation.

\section{Factors Influencing Salamanders in Riparian Forests}

\subsection{Overview of Factors}

Salamander populations in riparian forests are influenced by a plethora of independent and interacting factors, ranging in effect, spatial scale (e.g., microhabitat vs. landscape-level feature), and classification (e.g., anthropogenic vs. environmental). To identify and summarize the factors and their associated response patterns, we grouped each factor into two main categories: (1) local habitat and microhabitat features; and (2) anthropogenic activities. Based on published studies, we briefly describe and highlight the effects of each factor on terrestrial and stream salamander species.

The focus of the latter portion of this paper is on how anthropogenic activities affect salamander populations, but first we reviewed the influences of local habitat and microhabitat features to explain exactly how and why human activities are altering ecosystem functions. The habitat factors listed in Section 2.2 are each shaped by or connected to anthropogenic activities. For instance, to assess the impacts of prescribed fire, one must understand the relationship between salamander populations and leaf litter.

\subsection{Local Habitat and Microhabitat Features}

Understanding the relationship between environmental features and species populations is a key step in conserving habitat successfully. Local distributions of salamander species result from behavioral reactions to various environmental factors and physiological reactions based on the species' tolerance limits. These responses differ in respect to the habitat or microhabitat feature and by the species/group in question (Table 1). We looked at four main habitat components: stream quality, leaf litter and woody debris, riparian buffer width, and soil characteristics. Certain components, such as stream quality and soil characteristics, were broken down further into more specific categories, such as temperature and acidity. 
Table 1. General positive $(+)^{\mathrm{a}}$ and negative $(-){ }^{\mathrm{b}}$ associations $(p<0.05)$ of terrestrial and aquatic salamanders to water temperature (WT), water acidity $(\mathrm{WpH})$, leaf litter (LL), coarse woody debris (CWD), riparian buffer width (RPB), soil moisture (SM), and soil acidity $(\mathrm{SpH})$, within typical ranges. Neutral and undetermined associations are indicated by a “---".

\begin{tabular}{|c|c|c|c|c|c|c|c|c|}
\hline Species/Group & WT & WpH & $\mathbf{L L}$ & CWD & RBW & SM & SpH & Source(s) \\
\hline stream salamanders ${ }^{\mathrm{c}}$ & - & + & $\begin{array}{ll}-- \\
--\end{array}$ & + & --- & --- & --- & {$[48,57-59]$} \\
\hline mole salamanders & --- & + & --- & + & --- & + & + & {$[60-63]$} \\
\hline torrent salamanders & - & --- & + & + & + & + & + & {$[57,63-65]$} \\
\hline plethodontid salamanders & --- & --- & + & + & --- & + & + & {$[63,66-68]$} \\
\hline $\begin{array}{l}\text { red-backed salamander } \\
\text { (Plethodon cinereus) }\end{array}$ & --- & --- & + & + & --- & + & + & {$[63,66-68]$} \\
\hline $\begin{array}{c}\text { red-spotted newt } \\
\text { (Notophthalmus viridescens) }\end{array}$ & --- & --- & + & + & --- & --- & --- & {$[63,69]$} \\
\hline
\end{tabular}

a indicates presence of salamanders or a direct relationship with the variable; $b$ indicates absence of salamanders or an inverse relationship with the variable; ${ }^{c}$ includes desmognathines (Desmognathus spp.), two-lined salamanders (Eurycea spp.), and red salamanders (Pseudotriton ruber).

\subsubsection{Stream Quality}

There are several physical, chemical, and morphological parameters of the aquatic environment that are important when considering salamander population responses in riparian forests. Acidity, conductivity, temperature, substrate, sedimentation, and velocity can affect the physiology, ecology, and behavior of stream salamanders. For instance, Grant et al. [59] found that stream temperature limits salamander occupancy, and they suggest that temperature, specific conductance, and $\mathrm{pH}$ influence stream salamander distribution.

Acidic stream conditions can affect the distribution of salamanders, particularly the aquatic life stages [61,70]. In general, potential effects of acid deposition on amphibian species include increased mortality and depressed growth rates. More specifically, low $\mathrm{pH}$ can result in high egg mortality, decreased larval recruitment, and developmental anomalies [47,61,71,72]. Stream acidification and metal contamination can alter the structure of streamside salamander communities through direct species mortality and by altering ecological community interactions [48,71,73]. The presence of metals can negatively affect reproductive success and development [62,73,74]. Increased conductivity can also act as an environmental stressor for salamanders and affect prey consumption [58,75]. However, Klaver et al. [76] found that conductivity had no effect on barred tiger salamander (Ambystoma mavortium) occupancy, so responses may vary by species.

Temporal changes in temperature profiles can negatively affect development and survival $[57,71,72]$. Critical thermal maximum and preferred temperature values are often species-specific and may account for differences in distributions [77,78]. Elevation of stream temperatures could threaten species of torrent salamanders in the Pacific Northwest by causing physiological stress, and extended periods of exposure to warm water may be lethal to some salamanders $[65,78]$. In addition, temperature can play a role in disease ecology and infections. For instance, temperature has a strong influence on percent mortality and time to death of salamanders exposed to the Ambystoma tigrinum virus [79]. 
Stream channel morphology, substrate size and composition, and sedimentation can influence distribution or abundance. Heterogeneous streams with the presence of multiple microhabitats, such as a complex sequence of runs, riffles, and pools, are important for salamander larval development and abundance [80,81]. Hawkins et al. [82] found that the densities of salamanders in northwestern United States were correlated with substrate composition, specifically associated with high-gradient sites with coarse substrates. Because stream amphibians often use the interstitial spaces between rocks of the streambed to forage, hide, and lay eggs, sedimentation can reduce habitat and have a strong effect on abundance $[83,84]$. For instance, spring salamanders in New Hampshire are associated with low sediment levels [85].

The tolerance of stream salamanders to water quality parameters can determine population persistence within riparian forests. Other stream quality parameters that can affect salamander populations include turbidity and nutrient levels $[80,86]$. Salamanders are physiologically restricted to specific ranges of water quality parameter levels and appear to prefer certain microhabitats within those ranges.

\subsubsection{Leaf Litter and Woody Debris}

Many salamander species are associated with the presence of organic materials on the forest floor, such as moist leaf litter, which serves as ground cover and microhabitat. Absence or loss of litter increases exposure to temperature fluctuations and desiccation, elevates predation risk and physiological stress, and reduces dispersal and foraging ability [57,87]. For instance, juvenile plethodontid salamanders often forage and seek cover in moist leaf litter [63]. Rittenhouse et al. [69] found that adult red-spotted newts (Notophthalmus viridescens) were quick to respond to the presence of litter, using it as cover within their experiment testing substrate preferences.

Coarse woody debris (CWD) plays a critical role in providing microhabitats, offering stable, moist environments for terrestrial salamanders as well as cover for stream salamanders from predators [88]. Salamanders in streams are frequently associated with increased habitat complexity from instream woody debris and other aquatic cover [30,89]. During brief dry spells, red-backed salamanders (Plethodon cinereus) will retreat to seek cover under rocks or logs [67]. In an experiment comparing high and low density of cover objects, such as rocks, logs, and CWD, increased densities resulted in increased abundances of red-backed and northern slimy salamanders (Plethodon glutinosus) as well as red-backed salamanders with higher masses [63]. Cover object availability, such as the amount of CWD, could determine the foraging success of terrestrial salamanders [63]. The abundance of cover objects could even influence the abundance and composition of salamander communities in streamside and seep habitats [63,90-92]. In addition, solid objects, including CWD, can facilitate burrowing, which can be necessary to avoid desiccation [66].

Moist leaf litter and CWD are two significant microhabitat features that have great influence over terrestrial salamanders such as plethodontids. Anthropogenic activities that result in the absence or decrease of leaf litter and cover objects such as CWD will likely have negative impacts on local salamander populations. 


\subsubsection{Riparian Buffer Width}

Aquatic and terrestrial habitats are biologically interdependent, and the interaction between the two habitat types is essential for the persistence of salamander populations. Current forest practices tend to recommend or require riparian buffers along headwater and small streams. These buffer zones provide shade and reduce sediment and nutrient (e.g., road salts, nitrates, phosphates) loading from erosion and runoff due to anthropogenic activities such as timber harvest, prescribed burns, road maintenance, and agricultural practices. Buffers help to maintain stream conditions, such as hydrologic stability, across seasonal and climatic gradients as well as provide adjacent riparian habitat suitable for salamanders [10,58]. For instance, Pacific giant salamanders (Dicamptodon tenebrosus), southern torrent salamanders (Rhyacotriton variegatus) and Columbia torrent salamanders (Rhyacotriton kezeri) are positively associated with the presence of a band of forested streamside habitat [64].

The size of a stream buffer may have an effect on the relative abundance of salamanders. Forest buffer recommendations range from $6 \mathrm{~m}$ to retain stream and bank amphibians in small streams to $92.6 \mathrm{~m}$ to retain 95\% amphibian assemblages in southern Appalachian streams and buffer edge effects $[30,93,94]$. Forestry agencies tend to recommend widths of $10-30 \mathrm{~m}$, but the width that is generally acknowledged as effective to protect water resources is $30-60 \mathrm{~m}[4,95,96]$. When the focus is timber management, Olson et al. [30] suggest widths of $10 \mathrm{~m}$ for bank stability, 15-30 m for water quality and aquatic habitat features, and 40-100 m for riparian-dependent species. Plethodontid stream salamanders tend to remain within 20-30 m from aquatic habitats [95]. However, Rundio and Olson [97] found that streamside and variable-width buffers provide poor coverage, while one-tree height and two-tree height buffers were wide enough to support higher abundances of salamanders. Peterman and Semlitsch [98] found that larval salamanders are negatively affected by increased sedimentation and decreased riparian buffer width. Semlitsch and Bodie [95] state that large areas of terrestrial habitat surrounding wetlands are critical to maintaining biodiversity. Similarly, Olson et al. [30] assert that a conservation approach requires $40-150 \mathrm{~m}$ riparian management zones as well as patch reserves along headwater streams to connect drainages.

However, riparian buffers may not always be effective in conserving stream salamanders. Willson and Dorcas [58] found that the presence of a buffer along a stream had negligible beneficial effects on salamanders. Similarly, Miller et al. [99] found that larval abundance of southern two-lined salamanders (Eurycea cirrigera) was not affected by buffer width, perhaps due to an incomplete buffer system with multiple breaches. Furthermore, the effects of buffer treatments may be regulated by weather conditions [100]. In addition, some studies found that while buffer strips aid in habitat management for several salamander species, current requirements for riparian buffer widths may not provide adequate protection to preserve amphibian diversity [98,101]. Lee et al. [102] reviewed riparian buffer width guidelines from Canada and the United States and found that average buffer widths for various waterbody types in both countries ranged between 15 and $29 \mathrm{~m}$. However, they also concluded that while buffer widths for most jurisdictions were adequate for aquatic biota and habitat protection, they tended to be less than the recommended widths for terrestrial communities. Olson and Rugger [93] suggest maintaining a mix of buffer widths across watersheds. Ficetola et al. [103] advocate for a shift from core habitat buffers to more complex landscape buffers, which incorporate different landscape components, such as forest cover, roads, and hydrographic network. 
Riparian buffer zones are increasingly used to minimize the impacts of development on aquatic habitats. They protect water resources through physical and chemical filtration processes, reducing siltation and moderating increases in water temperature $[10,58,95]$. However, conservation efforts to protect salamander populations in small streams must balance the preservation of riparian buffers with a consideration of the land use throughout the watershed [10,58].

\subsubsection{Soil Characteristics}

Certain species of salamanders are restricted to a very specific range of environmental parameters. Soil characteristics of riparian forests, such as moisture and acidity, can be critical in determining the presence or abundance of salamanders, due to physiological and ecological constraints.

Soil moisture is often considered one of the primary factors influencing the occurrence of several salamander species, and in some cases, it is a basic requirement for survival. For instance, plethodontid salamanders are lungless and rely on cutaneous respiration; to sustain efficient gas exchange, their skin must be kept moist. Therefore, plethodontid salamanders are limited to moist environments and their activity is restricted to periods of high soil moisture [63,77,104-106]. Moisture may furthermore be a factor in the magnitude and timing of annual breeding migrations $[69,107]$. Soil moisture level has been shown to regulate the abundance of red-backed and northern slimy salamanders, with the presence of water increasing the number of juvenile red-backed salamanders as well as the activity levels of both juveniles and adults [63]. In addition, red-backed salamanders will retreat into the soil during a prolonged period of dryness [66]. In one experiment, juvenile spotted salamanders (Ambystoma maculatum) consistently selected saturated soil over dry soil [69]. Another study showed that substrate preference is generally based on moisture content rather than texture [108].

Acidity of soils is another important consideration, as low $\mathrm{pH}$ conditions can restrict the distributions of terrestrial salamanders, impact salamander growth and respiration, and disrupt the sodium balance of amphibian larvae [61,109,110]. Studies show that soil acidity may affect habitat selection of salamanders $[60,68]$. Soil $\mathrm{pH}$ has been shown to influence the density and distribution of red-backed salamanders in New York, which prefer substrates near neutral $\mathrm{pH}$ [110]. In the same study by Wyman and Hawksley-Lescault [110], juvenile salamanders were not found in areas where soil $\mathrm{pH}$ was $\leq 3.7$. Another study claimed that soil $\mathrm{pH}$ was more influential than soil moisture or light intensity in affecting salamander distribution [68].

Soil moisture and acidity can have significant influences on terrestrial salamanders and habitat selection. Anthropogenic activities that cause a decrease in soil moisture or an increase in $\mathrm{pH}$ will likely have negative impacts on local salamander populations. Other soil characteristics that may affect salamander distribution include temperature and classification [111,112].

\subsection{Anthropogenic Activities}

Humans have had an increasing and arguably disproportionate magnitude of impact on other species throughout the world. Some of our actions have directly resulted in the extinction and extirpation of many species, and they have caused others to become threatened or endangered [113,114]. Anthropogenic activities are among the leading reasons for population declines and shifts in distribution [31,114]. As such, it is critical that we understand how our actions affect species and alter the environment, especially with 
respect to vulnerable habitats and species, such as salamanders. For example, the physical and chemical conditions of headwater streams are closely linked to terrestrial inputs of nutrients, toxins, and sediment, which makes them sensitive to anthropogenic disturbance $[115,116]$. Consequently, salamanders and other headwater specialist taxa in the United States may be particularly vulnerable to human perturbation [27,117]. In this section, we identify five anthropogenic activities that have been shown to negatively impact salamander populations in riparian forests and examine the mechanisms behind their effects.

\subsubsection{Timber Harvest}

Observational and experimental studies have reported reductions in salamander populations following harvest. Timber harvest affects ecosystem structure, ecological processes, species diversity, and population viability. In some cases, intensive management of forest landscapes can degrade habitat quality for amphibian species, particularly in riparian systems. In general, short-term effects are negative, especially for salamanders [118]. Timber harvest in riparian forests can impact salamanders by limiting dispersal capabilities, decreasing leaf litter depth and canopy cover, and increasing exposure, air and water temperature, instability of microclimatic conditions, and soil compaction [111,119].

Most studies that examine the effects of clear-cuts on amphibians document higher abundance on control forest plots than on harvest plots, a trend that holds true for riparian forests $[98,120]$. deMaynadier and Hunter [118] found more than a threefold difference in amphibian abundance between control sites and clear-cuts. Salamanders in particular seem to be more sensitive to clear-cutting than other amphibian groups, and plethodontids experience some of the greatest population declines [118,119,121]. Recently harvested riparian forests may pose ecological traps for migrating salamanders, due to exposed conditions that could subject salamanders to heat and desiccation, reducing survival $[69,111,119]$. In southern Appalachian riparian forests, timber harvest can result in reduced leaf litter mass, depth, and moisture, and the elimination of canopy cover can increase soil temperature while decreasing surface soil moisture [111,121]. Timber harvest in Pacific Northwest riparian forests can increase stream temperatures, impacting cold-adapted stream amphibians, and restrict movement $[65,122]$. Clear-cut areas may also contain a lower percent cover of CWD and leaf litter [119]. In addition to decreased abundances, species richness tends to be lower in clear-cut plots compared to control sites [84,121]. Grialou et al. [119] noted that Columbia torrent salamanders and Pacific giant salamanders were absent from clear-cut areas. Other studies found a difference in species composition, while a few found no significant differences [see 118].

Salamander species-specific responses may vary by treatment, region, and amount of time since harvest. In low-elevation forests of Virginia, relative abundance of salamanders was lower after group selection, shelterwoods, leave-tree, and clear-cut harvest treatments, but there was no significant difference in relative abundance between control and understory removal treatments [123]. Of several oak regeneration options, Homyack and Haas [124] indicate that group selection harvest facilitates the quickest population recovery for salamanders. Thinning in Pacific Northwest riparian forests had no effect on species presence or size-class distribution [119]. Perkins and Hunter [125] conjecture that partial harvest is an effective way to maintain salamander communities along headwater streams, and Patrick et al. [126] found that spotted salamanders and eastern red-backed salamanders prefer uncut and partial-cut habitat, as 
well as retained CWD. Knapp et al. [120] believe that concentrating high-intensity timber harvesting (e.g., clearcuts) in areas only a few hectares in size would minimize declines in plethodontid abundance due to timber harvest. Crawford and Semlitsch [111] suggested uneven-aged timber harvest to protect stream amphibians. In Pennsylvania, amphibian abundance and species richness was positively correlated with remaining basal area in forests containing permanent or temporary water sources [127]. In addition, pre-existing site conditions, such as riparian buffers and CWD, may help to moderate the effects of forest management practices, like thinning [97].

Ford et al. [128] found that stand age following clear-cutting in cove hardwoods was an important factor in explaining salamander abundance and community composition, with the species richness and diversity of certain species highest in the oldest stands. Crawford and Semlitsch [111] discovered that stream salamanders had overall reduced abundance and terrestrial habitat use in stands less than 40 years old compared to more mature stands. Homyack and Haas [124] predicted that it would take $>60$ years for red-backed salamanders to reach pre-harvest levels of abundance, and Crawford and Semlitsch [111] estimated 40 years for an assemblage of seal, Ocoee (Desmognathus ocoee), and Blue Ridge two-lined salamanders (Eurycea wilderae) to recover. In contrast, Steele and Brodie [129] concluded that forest age had no effect on the densities of Pacific and Cope's giant salamanders (Dicamptodon copei). However, Steele et al. [130] did find that Cascade torrent salamanders (Rhyacotriton cascadae) were least abundant in young riparian forests $<25$ years in age.

Timber harvest is a widespread practice, and it is important to understand how different treatments affect how salamander species respond. Habitat management guidelines for salamanders should be incorporated into harvest operations. Some recommendations for managers of riparian forests to help maintain salamander populations include preserving logs and snags as moist microhabitats, retaining some understory to provide shade, and maintaining riparian buffer zones [122,131]. Partial harvest with limited canopy thinning may be a viable method to maintain salamander populations [126,132]. In addition, it is critical to maintain some level of landscape connectivity to allow for dispersal and genetic exchange.

\subsubsection{Prescribed Fire}

In the United States, prescription burning is a widely used method to reduce fuel and maintain healthy forests; thus, it is critical to understand the effects of controlled burns on riparian forest wildlife, particularly vulnerable species such as salamanders. Salamander populations can be affected by the presence of fire through direct mortality and through indirect effects on habitat structure and ecosystem function. Fire can alter habitats and increase or decrease invertebrate populations in riparian forests, which in turn affects food resources and interactions, competition, growth, and behavior. Biotic responses to a fire event vary temporally; they can be immediate (within several days), short-term (within one year), mid-term (within ten years), and long-term (beyond ten years) [133]. In addition to time scale, there are many other factors that may influence salamander responses to fire in a riparian forest, including species, season of burn, and location. However, several general trends can be inferred from observation and experimentation.

Although mortality of amphibians can be difficult to calculate in some instances, it is thought that direct mortality during fires is negligible and has little effect on overall populations [57,134]. Indirect effects due to habitat alteration can have more substantial impacts. For instance, thermal changes can negatively affect development and survival, especially species in riparian forests that are adapted to colder 
temperatures $[57,59,65]$. Other conditions resulting from a prescribed fire that can have negative associated effects on salamander growth and abundance in riparian forests include an increase in exposure to ultraviolet-B, sedimentation due to fire-induced erosion, loss of moist leaf litter, removal of woody debris, and declines in local insect populations $[57,135,136]$.

Pilliod et al. [57] proposed three responses of different amphibians to fire and fire-related changes in habitat over time: (1) species that are at first sensitive to disturbance benefit in the long-term from productivity increases; (2) species experience an increase in density due to predator and competitive release as well as opening the forest canopy; and (3) rare, sensitive species with low densities or limited distribution are negatively affected and their populations drop quickly. As demonstrated by those predictions, the impact of prescribed fires on salamander populations in riparian forests is not wholly negative. Changes in hydroperiods and the formation of small pools due to vegetation and hydrology changes induced by fires may benefit some salamanders [57]. In addition, a wildfire in California reduced cannibalism among California newts (Taricha torosa) by increasing prey availability [137]. Additional possible benefits for salamanders in riparian forests include increased habitat heterogeneity and the creation of breeding habitat $[57,138,139]$. Due to the variation in factors that play a role in salamanders' responses to fire, there are exceptions to the general trends discussed previously, as well as the possibility for neutral outcomes [135,139,140]. For example, Ford et al. [139] found that salamanders in riparian forest areas of the southern Appalachians exhibited no change in response to a prescribed fire.

It is important to understand salamander population responses to prescribed fire in order to make wise management decisions. However, because of the diversity in ecology and life histories of salamanders, the dynamic nature of fire, and the lack of comprehensive data, it is important to continue investigating the short-term, mid-term, and long-term effects of prescribed fires in riparian forest areas before making generalizations about recommendations.

\subsubsection{Urbanization}

Urbanization, a combination of increased human population density and landscape alteration, is associated with both habitat loss and fragmentation, and is cited as a potential contributor to recent amphibian population declines [141,142]. As human populations grow and change the landscape, it is critical to evaluate and manage the effects of urbanization on species dynamics. Urbanization can negatively affect natural riparian forest ecosystems by changing stream morphology, increasing run-off and soil erosion, removing trees, adding chemical pollutants, decreasing ground cover, and physical scouring $[99,141,143]$.

Many studies have shown that urbanization in riparian forests poses a threat to stream salamanders. Urbanization can lead to a decrease in riparian habitat or limit the ecosystem services provided by riparian forests that benefit salamanders, such as the abilities to maintain a relatively stable hydrologic regime and to reduce nutrient loading. Researchers estimated that the conversion of riparian forest to urban land near Davidson, North Carolina, resulted in the decline of southern two-lined salamander populations by up to $44 \%$ [144]. Investigations concerning the effects of urbanization on both adult and larval stages of salamanders found that urbanization was associated with decreases in survival and colonization probabilities $[145,146]$. Another study asserted that high water velocities in urban streams, due to increased amounts of impervious surfaces and loss of riparian forests in watersheds, resulted in decreased larval 
salamander retention [42]. Similarly, increasing impervious surface cover led to decreasing abundances of larval southern two-lined salamanders in North Carolina [99]. Orser and Shure [143] found that dusky salamander population densities estimated along an urbanization gradient of streams near Atlanta, Georgia, were inversely related to the degree of urbanization. Differences in salamander densities were attributed to increased runoff and erosion in disturbed areas as well as increased instability of bank soils and decreased ground cover due to the absence of riparian forest [143]. In addition, a study in California found that streams in more developed watersheds tended to have exotic crayfish and fish, less diverse benthic macroinvertebrate communities, and fewer native species [141].

Although many studies have found that spreading urbanization can reduce or decimate salamander populations in riparian forests $[42,99,143-146]$, there is a need for more research on the mechanisms that drive those responses. It is important to know how urbanization impacts stream habitat so that we can mitigate changes in stream morphology and subsequent shifts in salamander populations. For instance, restoration and mitigation efforts that reduce run-off in urban areas, such as creating and maintaining riparian buffers, can improve stream habitat quality for salamanders.

\subsubsection{Roads}

Forest road networks have expanded in recent decades. However, these roads can act as both mortality agents and physical barriers to the movement and dispersal of several animals, including small mammals, butterflies, and snails [147,148]. The obstructive nature of roads is particularly important to consider in relation to salamanders in riparian forests, due to their small size and physiological constraints. Dispersal is an essential stage in the life-history of many salamanders, and thus, hindrances to movement must be accounted for when planning landscape-level conservation strategies for salamanders.

The presence of roads and traffic intensity can result in the direct mortality of amphibian species [149,150]. For instance, a study in Canada found that with increasing traffic intensity, the proportion of dead frogs and toads increased while the density decreased [149]. Another study, which recorded the deaths of newt and frog species during attempted road crossings, determined that velocity of the species and diurnal movement pattern of both species and vehicles influenced likelihood of road mortality [151].

The impact of roads on salamanders in riparian forests is compounded by edge effects, which result in unsuitable habitat along a boundary. Edge effects in forested habitat include changes in abiotic conditions, altered rates of predation and competition, and shifting community structure [52,152]. Microhabitat features such as soil moisture and cover object area tend to decrease in the proximity of roads [52]. In addition, roads can reduce edge permeability due to factors such as behavioral aversion and increased mortality from road crossing [147,153]. Gibbs [147] found that roads appeared to be a significant anthropogenic landscape component restricting salamander movement. Multiple studies have found that roads negatively affect salamander abundance [52,147,152,153]. For instance, red-backed salamanders are significantly less abundant near gravel road edges, perhaps due to corresponding lower soil moisture [52]. Similarly, the abundance of riparian forest-dependent salamanders, such as plethodontids, is much reduced along both active and abandoned logging roads [152]. Roads can also restrict salamander movement due to impassable culverts and result in decreased abundance and richness in streams $[153,154]$. 
Road construction can increase mortality and lower the quality of surrounding forest for several terrestrial salamanders. It is possible that limiting or changing road traffic and maintenance strategies that decrease soil moisture would result in less disruption to salamander populations [52]. However, it is important to continue investigating the edge effects of roads to conserve wildlife populations and guide road policy and maintenance strategies.

\subsubsection{Habitat Loss and Fragmentation}

Habitat loss and fragmentation is a major threat to interior riparian forest species, changing both species abundance and community structure. Deforestation and habitat fragmentation are two of the main reasons for declines in herpetofaunal species $[114,155]$. Fragmenting natural habitats alters the shape, size, and arrangement of habitat types, which in turn may exacerbate local extinction rates and impact dispersal patterns. Habitat fragmentation can act as a barrier that separates subpopulations $[155,156]$. Because their populations are both spatially and temporally dynamic, amphibians may be particularly prone to local extinction events.

Red-spotted newts seem to occur more frequently in interior locations within forests [147,148,157]. Although it took place in an upland forest, one study suggested that red-spotted newts have a behavioral avoidance of forest edges, which could reduce dispersal of the terrestrial efts [147]. Another study classified red-spotted newts as particularly vulnerable to population collapse due to riparian forest fragmentation [148]. Edge effects can vary in their severity depending on the species. Although deMaynadier and Hunter [158] noticed that red-backed salamander and mole salamander abundances decreased within certain distances from the forest edge, Gibbs [147] found that red-backed salamanders were more resistant to habitat fragmentation than spotted salamanders or red-spotted newts. In addition, Anderson et al. [157] discovered that northern slimy salamanders were more abundant in interior than edge locations while red-backed salamanders were captured equally in both locations. Species' vulnerability to negative fragmentation effects is thought to be correlated with low population density, along with habitat specificity and high dispersal ability. In addition to affecting abundance, forest fragmentation may influence biodiversity. A study in Madagascar found that both species richness and diversity were positively correlated with fragment size, possibly due to the homogeneity of vegetation structure and adverse microclimate conditions in the smaller fragments [159]. However, species richness is decided by not only the size of an area, but also its shape, variety of structures, and presence of water bodies. In a study that examined the effect of fragmentation on the genetic structure of red-backed salamanders in riparian forests, both molecular and morphological markers indicated that levels of genetic divergence between subpopulations were enhanced [160]. Becker et al. [161] identified another aspect of habitat fragmentation, which they termed "habitat split" and defined as a human-caused disconnect between habitats used by species in different life history stages. Specifically, they found that habitat split decreases the richness of species with aquatic larvae [161]. Although their study focused predominantly on frogs in the Brazilian Atlantic Forest, this mechanism could apply in North American riparian forests to salamander species with both terrestrial and aquatic life stages.

Information concerning abundance and density, as well as fitness measurements, along fragmentation gradients would be useful for conservation planning [148,155]. Habitat fragmentation is a landscape-level issue, and it is important to consider it at an appropriate spatial scale and perspective. Landscape 
connectivity plays a key role in regional viability of populations and may be essential to sustaining certain salamander species, such as the red-spotted newt. Source populations and dispersal pathways within human-disrupted landscapes must be located and protected, especially when addressing regional population declines [56,117]. For instance, Olson and Burnett [156] propose that headwater ridgelines in the Pacific Northwest be managed as "linkage areas" to provide habitat connectivity. Furthermore, we must consider how landscape-level disturbance regimes may impact localized edge effects [157].

\section{Discussion and Conclusions}

Salamanders and riparian forests are intimately interconnected. Salamanders are integral to ecosystem functions, contributing to vertebrate biomass and complex food webs in riparian forests. Specifically, many salamanders have essential roles in detritus food webs, and their population densities and distributions likely influence the structure and function of decomposer communities [33,34,110]. In turn, these forests provide critical habitat to salamander populations in the United States. For example, Petranka and Smith [3] reported that riparian forests in the southern Appalachians functioned as core habitat for 37\% of the salamander species encountered in their study. In the Pacific Northwest, all 30 native salamanders use or require riparian forests for breeding, rearing, and/or foraging habitat [30]. However, our knowledge of the distributions and habitat associations of aquatic and terrestrial salamanders in riparian forests is not comprehensive. Therefore, it is critical to research habitat requirements and preferences, as well as study interactions within the biotic community and analyze landscape-level data. We must measure and synthesize population changes among habitats in order to conserve local, regional, and global species richness and diversity. The need for strategic conservation of salamanders is critical because many species are restricted in geographical range or to localized microhabitats, which make them more vulnerable to both natural disturbances and anthropogenic activities. At least four federally listed endangered or threatened salamander species in the United States are associated with forested habitats [118]. For instance, the Cheat Mountain salamander (Plethodon nettingi) is a woodland species that is threatened and endemic to the Allegheny Mountains of eastern West Virginia. One of its main threats is the degradation of high-elevation red spruce and northern hardwood forests within its limited range [162]. Similarly, hellbenders (Cryptobranchus alleganiensis), an aquatic salamander species found in the eastern United States, require swift-running, unpolluted streams with riffle areas and plentiful cover objects; however, they are endangered in multiple states, in part due to anthropogenic activities that result in habitat loss and stream pollution.

Forested riparian areas are crucial for sustaining native herpetofaunal communities, yet human interactions with forests and streams are widespread and can be detrimental to the environment. This review of salamander population responses to a variety of environmental and anthropogenic factors may inform research and conservation decisions regarding salamander management in riparian forests. Salamanders have specific local habitat and microhabitat requirements and preferences. Distribution and population vitality of salamander species are influenced by stream quality parameters, the presence of leaf litter and woody debris, riparian buffer width, and soil characteristics. Human-caused disturbance, including timber harvest, prescribed fires, urbanization, road construction, and habitat fragmentation, alter these habitat factors within riparian forests. Timber harvest can increase salamander susceptibility to desiccation, while prescribed fire can result in the loss of moist leaf litter, thermal changes, and 
removal of woody debris $[57,69,118,135,136]$. Urbanization impacts stream salamanders, and roads contribute to habitat fragmentation, which restricts dispersal and may lead to extirpations of local species [52,99,143-145,148]. These impacts on habitats, biotic communities, and animal behavior generally elicit a corresponding change in salamander species diversity, density, and abundance. Our knowledge of this subject is not comprehensive, but with continued research, information on salamander responses to timber harvest and other significant anthropogenic activities in riparian forests can assist land and natural resource managers in assessing the benefits or anticipating the consequences of proposed plans.

\section{Acknowledgments}

Funding and logistical support was provided by the West Virginia University (WVU) Division of Forestry and Natural Resources, the WVU Environmental Research Center, and McIntire-Stennis formula funds. This is scientific article 3221 of the WVU Agricultural and Forestry Experiment Station.

\section{Author Contributions}

Hannah L. Clipp. Responsible for literature review, writing, and revision process; James $\mathrm{T}$. Anderson. Assisted in idea development and revision process.

\section{Conflicts of Interest}

The authors declare no conflict of interest.

\section{References}

1. Anbumozhi, V.; Radhakrishnan, J.; Yamaji, E. Impact of riparian buffer zones on water quality and associated management considerations. Ecol. Eng. 2005, 24, 517-523.

2. Jordan, T.E.; Correll, D.L.; Weller, D.E. Nutrient interception by a riparian forest receiving inputs from adjacent cropland. J. Environ. Qual. 1993, 22, 467-473.

3. Petranka, J.W.; Smith, C.K. A functional analysis of streamside habitat use by southern Appalachian salamanders: Implications for riparian forest management. For. Ecol. Manag. 2005, 210, 443-454.

4. Clinnick, P.F. Buffer strip management in forest operations: A review. Austral. For. 1985, 48, 34-45.

5. Lowrance, R. Groundwater nitrate and denitrification in a coastal plain riparian forest. $J$. Environ. Qual. 1992, 21, 401-405.

6. Macdonald, J.S.; MacIsaac, E.A.; Herunter, H.E. The effect of variable-retention riparian buffer zones on water temperatures in small headwater streams in sub-boreal forest ecosystems of British Columbia. Can. J. For. Res. 2003, 33, 1371-1382.

7. Peterjohn, W.T.; Correll, D.L. Nutrient dynamics in an agricultural watershed: Observations on the role of a riparian forest. Ecology 1984, 65, 1466-1475.

8. Lowrance, R.; Altier, L.S.; Newbold, J.D.; Schnabel, R.R.; Groffman, P.M.; Denver, J.M.; Correll, D.L.; Gilliam, J.W.; Robinson, J.L.; Brinsfield, R.B.; et al. Water quality functions of riparian forest buffers in Chesapeake Bay watersheds. Environ. Manag. 1997, 21, 687-712. 
9. Sheridan, J.M.; Lowrance, R.; Bosch, D.D. Management effects on runoff and sediment transport in riparian forest buffers. Trans. Am. Soc. Agric. Eng. 1999, 42, 55-64.

10. Marczak, L.B.; Sakamaki, T.; Turvey, S.L.; Deguise, I.; Wood, S.L.R.; Richardson, J.S. Are forested buffers an effective conservation strategy for riparian fauna? An assessment using Meta-analysis. Ecol. Appl. 2010, 20, 126-134.

11. Nakano, S.; Murakami, M. Reciprocal subsidies: Dynamic interdependence between terrestrial and aquatic food webs. Proc. Nat. Acad. Sci. USA 2001, 98, 166-170.

12. Naiman, R.J.; Décamps, H.; Pollock, M. The role of riparian corridors in maintaining regional biodiversity. Ecol. Appl. 1993, 3, 209-212.

13. Sabo, J.L.; Sponseller, R.; Dixon, M.; Grade, K.; Harms, T.; Heffernan, J.; Jani, A.; Katz, G.; Soykan, C.; Watts, J.; Welter, J. Riparian zones increase regional species richness by harboring different, not more, species. Ecology 2005, 86, 56-62.

14. Brabec, E.; Schulte, S.; Richards, P.L. Impervious surfaces and water quality: A review of current literature and its implications for watershed planning. J. Plan. Lit. 2002, 16, 499-514.

15. Pappas, E.A.; Smith, D.R.; Huang, C.; Shuster, W.D.; Bonta, J.V. Impervious surface impacts to runoff and sediment discharge under laboratory rainfall simulation. Catena 2008, 72, 146-152.

16. Nilsson, C.; Grelsson, G.; Johansson, M.; Sperens, U. Patterns of plant species richness along riverbanks. Ecology 1989, 70, 77-84.

17. Kalliola, R.; Puhakka, M. River dynamics and vegetation mosaicism: A case study of the River Kamajohka, northernmost Finland. J. Biogeogr. 1988, 15, 703-719.

18. Kalliola, R.; Salo, J.; Puhakka, M.; Rajasilta, M. New site formation and colonizing vegetation in primary succession on the western Amazon floodplains. J. Ecol. 1991, 79, 877-901.

19. Salo, J.; Kalliola, R.; Hakkinen, I.; Makinen, Y.; Niemela, P.; Puhakka, M.; Coley, P.D. River dynamics and the diversity of Amazon lowland forest. Nature 1986, 322, 254-258.

20. Tabacchi, E.; Planty-Tabacchi, A.M.; Décamps, O. Continuity and discontinuity of the riparian vegetation along a fluvial corridor. Landsc. Ecol. 1990, 5, 9-20.

21. Decamps, H.; Tabacchi, E. Species richness in riparian vegetation along river margins. In Aquatic Ecology: Scale, Pattern and Process; Giller, P., Hildrew, A., Rafaelli, D., Eds.; Blackwell: London, UK, 1993.

22. Gregory, S.V.; Swanson, F.J.; McKee, W.A.; Cummins, K.W. An ecosystem perspective of riparian zones. BioScience 1991, 41, 540-551.

23. Junk, W. Flood tolerance and tree distribution in central Amazonian floodplains. In Tropical Forests: Botanical Dynamics, Speciation, and Diversity; Holm-Nielsen, L.B., Nielsen, I.C., Balsley, H., Eds.; Academic Press: Orlando, FL, USA, 1989; pp. 47-64.

24. Raedeke, K. Streamside management: Riparian wildlife and forestry interactions. Contribution Number 59; Institute of Forest Resources, University of Washington: Seattle, WA, USA, 1989.

25. Richardson, J.S.; Naiman, R.J.; Swanson, F.J.; Hibbs, D.E. Riparian communities associated with Pacific Northwest headwater streams: Assemblages, processes, and uniqueness. J. Am. Water Res. Assoc. 2005, 41, 935-947.

26. Richardson, J.S.; Danehy, R.J. A synthesis of the ecology of headwater streams and their riparian zones in temperate forests. For. Sci. 2007, 53, 131-147. 
27. Meyer, J.L.; Strayer, D.L.; Wallace, J.B.; Eggert, S.L.; Helfman, G.S.; Leonard, N.E. The contribution of headwater streams to biodiversity in river networks. J. Am. Water Res. Asoc. 2007, 43, 86-103.

28. Brode, J.M.; Bury, R.B. The importance of riparian systems to amphibians and reptiles. In California Riparian Systems: Ecology, Conservation, and Productive Management; Warner, R.E., Hendrix, K.M., Eds.; University of California Press: Berkeley, CA, USA, 1984; pp. 30-36.

29. Burton, T.M.; Likens, G.E. Salamander populations and biomass in the Hubbard Brook Experimental Forest, New Hampshire. Copeia 1975, 1975, 541-546.

30. Olson, D.H.; Anderson, P.D.; Frissell, C.A.; Welsh, H.H.; Bradford, D.F. Biodiversity management approaches for stream-riparian areas: Perspectives for Pacific Northwest headwater forests, microclimates, and amphibians. For. Ecol. Manag. 2007, 246, 81-107.

31. Hamer, A.J.; McDonnell, M.J. Amphibian ecology and conservation in the urbanizing world: A review. Biol. Conserv. 2008, 141, 2432-2449.

32. Peterman, W.E.; Crawford, J.A.; Semlitsch, R.D. Productivity and significance of headwater streams: Population structure and biomass of the black-bellied salamander (Desmognathus quadramaculatus). Freshw. Biol. 2008, 53, 347-357.

33. Davic, R.D.; Welsh, H.H., Jr. On the ecological roles of salamanders. Annu. Rev. Ecol. Evol. Syst. 2004, 35, 405-434.

34. Wyman, R.L. Experimental assessment of salamanders as predators of detrital food webs: Effects on invertebrates, decomposition, and the carbon cycle. Biodivers. Conserv. 1998, 7, 641-650.

35. Burton, T.M.; Likens, G.E. Energy flow and nutrient cycling in salamander populations in the Hubbard Brook Experimental Forest, New Hampshire. Ecology 1975, 56, 1068-1080.

36. Welsh, H.H., Jr.; Droege, S. A case for using plethodontid salamanders for monitoring biodiversity and ecosystem integrity of North American forests. Conserv. Biol. 2002, 15, $558-569$.

37. Southerland, M.T.; Jung, R.E.; Baxter, D.P.; Chellman, I.C.; Mercurio, G.; Vølstad, J.H. Stream salamanders as indicators of stream quality in Maryland, USA. Appl. Herpetol. 2004, 2, 23-46.

38. Welsh, H.H., Jr.; Ollivier, L.M. Stream amphibians as indicators of ecosystem stress: A case study from California's redwoods. Ecol. Appl. 1998, 8, 1118-1132.

39. Johnson, B.R.; Fritz, K.M.; Blocksom, K.A.; Walters, D.M. Larval salamanders and channel geomorphology are indicators of hydrologic permanence in forested headwater streams. Ecol. Indic. 2009, 9, 150-159.

40. Moore, E.L, Jr. An index of biotic integrity for macroinvertebrates and salamanders in primary headwater habitat streams in Ohio. Master Thesis, the Ohio State University, Columbus, OH, USA, 2010.

41. Green, D.M. The ecology of extinction: Population fluctuation and decline in amphibians. Biol. Conserv. 2003, 111, 331-343.

42. Barrett, K.; Guyer, C. Differential responses of amphibians and reptiles in riparian and stream habitats to land use disturbances in western Georgia, USA. Biol. Conserv. 2008, 141, 2290-2300.

43. Barrett, K.; Helms, B.S.; Guyer, C.; Schoonover, J.E. Linking process to pattern: Causes of stream-breeding amphibian decline in urbanized watersheds. Biol. Conserv. 2010, 143, 1998-2005. 
44. Corser, J.D. Decline of disjunct green salamander (Aneides aeneus) populations in the southern Appalachians. Biol. Conserv. 2001, 97, 119-126.

45. Bank, M.S.; Crocker, J.B.; Davis, S.; Brotherton, D.K.; Cook, R.; Behler, J.; Connery, B. Population decline of northern dusky salamanders at Acadia National Park, Maine, USA. Biol. Conserv. 2006, 130, 230-238.

46. Lowe, W.H. Climate change is linked to long-term decline in a stream salamander. Biol. Conserv. 2012, 145, 48-53.

47. Harte, J.; Hoffman, E. Possible effects of acidic deposition on a Rocky Mountain population of the tiger salamander Ambystoma Tigrinum. Conserv. Biol. 1989, 3, 149-158.

48. Kucken, D.J.; Davis, J.S.; Petranka, J.W.; Smith, C.K. Anakeesta stream acidification and metal contamination: Effects on a salamander community. J. Environ. Qual. 1994, 23, 1311-1317.

49. Wang, X.; Zhang, K.; Wang, Z.; Ding, Y.; Wu, W.; Huang, S. The decline of the Chinese giant salamander Andrias davidianus and implications for its conservation. Oryx 2004, 38, 197-202.

50. Alford, R.A.; Richards, S.J. Global amphibian declines: A problem in applied ecology. Annu. Rev. Ecol. Syst. 1993, 30, 133-165.

51. Howard, J.H.; Baldwin, R.F.; Brown, B.L. Exploratory analysis for complex-life-cycle amphibians: Revealing complex forest-reproductive effort relationships using redundancy analysis. For. Ecol. Manag. 2012, 270, 175-182.

52. Marsh, D.M.; Beckman, N.G. Effects of forest roads on the abundance and activity of terrestrial salamanders. Ecol. Appl. 2004, 14, 1882-1891.

53. Surasinghe, T. Influences of Riparian Land-Uses on Habitat Use and Interspecific Competition of Stream-Dwelling Salamanders: Evidence from Blue Ridge \& Piedmont. Ph.D. Thesis, Clemson University, Clemson, SC, USA, 2013.

54. Cecala, K.K. The Role of Behavior in Influencing Headwater Salamander Responses to Anthropogenic Development. Ph.D. Thesis, University of Georgia, Athens, GA, USA, 2012.

55. Lowe, W.H. Linking dispersal to local population dynamics: A case study using a headwater salamander system. Ecology 2003, 84, 2145-2154.

56. Grant, E.H.C.; Nichols, J.D.; Lowe, W.H.; Fagan, W.F. Use of multiple dispersal pathways facilitates amphibian persistence in stream networks. Proc. Natl. Acad. Sci. USA 2010, 107, 6936-6940.

57. Pilliod, D.S.; Bury, R.B.; Hyde, E.J.; Pearl, C.A.; Corn, P.S. Fire and amphibians in North America. For. Ecol. Manag. 2003, 178, 163-181.

58. Willson, J.D.; Dorcas, M.E. Effects of habitat disturbance on stream salamanders: Implications for buffer zones and watershed management. Conserv. Biol. 2003, 17, 763-771.

59. Grant, E.H.C.; Wiewel, A.N.M.; Rice, K.C. Stream-water temperature limits occupancy of salamanders in mid-Atlantic protected areas. J. Herpetol. 2014, 48, 45-50.

60. Mushinsky, H.R. Selection of substrate pH by salamanders. Am. Midl. Nat. 1975, 93, 440-443.

61. Pierce, B.A. Acid tolerance in amphibians. BioScience 1985, 35, 239-343.

62. Horne, M.T.; Dunson, W.A. Toxicity of metals and low $\mathrm{pH}$ to embryos and larvae of the Jefferson salamander, Ambystoma jeffersonianum. Arch. Environ. Contam. Toxicol. 1995, 29, $110-114$. 
63. Grover, M.C. Influence of cover and moisture on abundances of the terrestrial salamanders Plethodon cinereus and Plethodon glutinosus. J. Herpetol. 1998, 32, 489-497.

64. Stoddard, M.A.; Hayes, J.P. The influence of forest management on headwater stream amphibians at multiple spatial scales. Ecol. Appl. 2005, 15, 811-823.

65. Bury, R.B. Low thermal tolerances of stream amphibians in the Pacific Northwest: Implications for riparian and forest management. Appl. Herpetol. 2008, 5, 63-74.

66. Heatwole, H. Burrowing ability and behavioral responses to desiccation of the salamander, Plethodon cinereus. Ecology 1960, 41, 661-668.

67. Jaeger, R.G. Microhabitats of a terrestrial forest salamander. Copeia 1980, 1980, 265-268.

68. Sugalski, M.T.; Claussen, D.L. Preference for soil moisture, soil pH, and light intensity by the salamander, Plethodon cinereus. J. Herpetol. 1997, 31, 245-250.

69. Rittenhouse, T.A.G.; Doyle, M.C.; Mank, C.R.; Rothermel, B.B.; Semlitsch, R.D. Substrate cues influence habitat selection by spotted salamanders. J. Wildl. Manag. 2004, 68, 1151-1158.

70. Grant, E.H.C.; Jung, R.E.; Rice, K.C. Stream salamander species richness and abundance in relation to environmental factors in Shenandoah National Park, Virginia. Am. Midl. Nat. 2005, 153, 348-356.

71. Pough, F.H.; Wilson, R.E. Acid precipitation and reproductive success of Ambystoma salamanders. Water Air Soil Poll. 1977, 7, 307-316.

72. Griffithsand, R.A.; de Wijer, P. Differential effects of $\mathrm{pH}$ and temperature on embryonic development in the British newts (Triturus). J. Zool. 1994, 234, 613-622.

73. Horne, M.T.; Dunson, W.A. Exclusion of the Jefferson salamander, Ambystoma jeffersonianum, from some potential breeding ponds in Pennsylvania: Effects of $\mathrm{pH}$, temperature, and metals on embryonic development. Arch. Environ. Con. Tox. 1994, 27, 323-330.

74. Horne, M.T.; Dunson, W.A. Effects of low pH, metals, and water hardness on larval amphibians. Arch. Environ. Con. Tox. 1995, 29, 500-505.

75. Chambers, D.L. Increased conductivity affects corticosterone levels and prey consumption in larval amphibians. J. Herpetol. 2011, 45, 219-223.

76. Klaver, R.W.; Peterson, C.R.; Patla, D.A. Influence of water conductivity on amphibian occupancy in the Greater Yellowstone ecosystem. Western N. Am. Nat. 2013, 73, 184-197.

77. Spotila, J.R. Role of temperature and water in the ecology of lungless salamanders. Ecol. Monogr. 1972, 42, 95-125.

78. Hutchison, V.H. Critical thermal maxima in salamanders. Physiol. Zool. 1961, 34, 92-125.

79. Rojas, S.; Richards, K.; Jancovich, J.K.; Davidson, E.W. Influence of temperature on Ranavirus infection in larval salamanders Ambystoma tigrinum. Dis. Aquat. Org. 2005, 63, 95-100.

80. Manenti, R.; Ficetola, G.F.; de Bernardi, F. Water, stream morphology, and landscape: Complex habitat determinants for the fire salamander Salamandra salamandra. Amphibia-Reptilia 2009, 30, 7-15.

81. Barr, G.E.; Babbitt, K.J. Effects of biotic and abiotic factors on the distribution and abundance of larval salamanders (Eurycea bislineata) across spatial scales. Oecologia 2002, 133, 176-185.

82. Hawkins, C.P.; Murphy, M.L.; Anderson, N.H.; Wilzbach, M.A. Density of fish and salamanders in relations to riparian canopy and physical habitat in streams of the northwestern United States. Can. J. Fish. Aq. Sci. 1983, 40, 1173-1185. 
83. Lowe, W.H.; Nislow, K.H.; Bolger, D.T. Stage-specific and interactive effects of sedimentation and trout on a headwater stream salamander. Ecol. Appl. 2004, 14, 164-172.

84. Corn, P.S.; Bury, R.B. Logging in western Oregon: Responses of headwater habitats and stream amphibians. For. Ecol. Manag. 1989, 29, 39-57.

85. Lowe, W.H.; Bolger, D.T. Local and landscape-scale predictors of salamander abundance in New Hampshire headwater streams. Conserv. Biol. 2002, 16, 183-193.

86. Secondi, J.; Aumjaud, A.; Pays, O.; Boyer, S.; Montembault, D.; Violleau, D. Water turbidity affects the development of sexual morphology in the palmate newt. Ethology 2007, 113, 711-720.

87. McLeod, R.F.; Gates, J.E. Response of herpetofaunal communities to forest cutting and burning at Chesapeake Farms, Maryland. Am. Midl. Nat. 1998, 139, 164-177.

88. Bragg, D.C.; Kershner, J.L. Coarse woody debris in riparian zones: Opportunity for interdisciplinary interaction. J. For. 1999, 97, 30-35.

89. Wilkins, R.N.; Peterson, N.P. Factors related to amphibian occurrence and abundance in headwater streams draining second-growth Douglas-fir forests in southwestern Washington. For. Ecol. Manag. 2000, 139, 79-91.

90. Southerland, M.T. The effects of variation in streamside habitats on the composition of mountain salamanders. Copeia 1986, 1986, 731-741.

91. Kleeburger, S.R. Influence of intraspecific density and cover on home range of a plethodontid salamander. Oecologia 1985, 66, 404-410.

92. Parker, M.S. Relationship between cover availability and larval Pacific giant salamander density. J. Herpetol. 1991, 25, 355-357.

93. Olson, D.H.; Rugger, C. Preliminary study of the effects of headwater riparian reserves with upslope thinning on stream habitats and amphibians in western Oregon. For. Sci. 2007, 53, 331-342.

94. Crawford, J.A.; Semlitsch, R.D. Estimation of core terrestrial habitat for stream-breeding salamanders and delineation of riparian buffers for protection of biodiversity. Conserv. Biol. 2007, 21, 152-158.

95. Semlitsch, R.D.; Bodie, J.R. Biological criteria for buffer zones around wetlands and riparian habitats for amphibians and reptiles. Conserv. Biol. 2003, 17, 1219-1228.

96. Broadmeadow, S.; Nisbet, T.R. The effects of riparian forest management on the freshwater environment: A literature review of best management practice. Hydrol. Earth Syst. Sci. 2004, 8, 286-305.

97. Rundio, D.E.; Olson, D.H. Influence of headwater site conditions and riparian buffers on terrestrial salamander response to forest thinning. For. Sci. 2007, 53, 320-330.

98. Peterman, W.E.; Semlitsch, R.D. Efficacy of riparian buffers in mitigating local population declines and the effects of even-aged timber harvest on larval salamanders. For. Ecol. Manag. 2009, 257, 8-14.

99. Miller, J.E.; Hess, G.R.; Moorman, C.E. Southern two-lined salamanders in urbanizing watersheds. Urban Ecosyst. 2007, 10, 73-85.

100. Veysey, J.S.; Babbitt, K.J.; Cooper, A. An experimental assessment of buffer width: Implications for salamander migratory behavior. Biol. Conserv. 2009, 142, 2227-2239. 
101. Vesely, D.G.; McComb, W.C. Salamander abundance and amphibian species richness in riparian buffer strips in the Oregon Coast Range. For. Sci. 2002, 48, 291-297.

102. Lee, P.; Smyth, C.; Boutin, S. Quantitative review of riparian buffer width guidelines from Canada and the United States. J. Environ. Manag. 2004, 70, 165-180.

103. Ficetola, G.F.; Padoa-Schioppa, E.; de Bernardi, F. Influence of landscape elements in riparian buffers on the conservation of semiaquatic amphibians. Conserv. Biol. 2009, 23, 114-123.

104. Heatwole, H. Environmental factors influencing local distribution and activity of the salamander, Plethodon cinereus. Ecology 1962, 43, 460-472.

105. Peterman, W.E.; Semlitsch, R.D. Fine-scale habitat association of a terrestrial salamander: The role of environmental gradients and implications for population dynamics. PLOS ONE 2013, 8, e62184.

106. Feder, M.E. Integrating the ecology and physiology of plethodontid salamanders. Herpetologica 1983, 39, 291-310.

107. Semlitsch, R.D. Analysis of climatic factors influencing migrations of the salamander Ambystoma talpoideum. Copeia 1985, 1985, 477-489.

108. Jaeger, R.G. Moisture as a factor influencing the distributions of two species of terrestrial salamanders. Oecologia 1971, 6, 191-207.

109. Freda, J.; Dunson, W.A. Sodium balance of amphibian larvae exposed to low environmental $\mathrm{pH}$. Physiol. Zool. 1984, 57, 435-443.

110. Wyman, R.L.; Hawksley-Lescault, D.S. Soil acidity affects distribution, behavior, and physiology of the salamander Plethodon cinereus. Ecology 1987, 68, 1819-1827.

111. Crawford, J.A.; Semlitsch, R.D. Post-disturbance effects of even-aged timber harvest on stream salamanders in southern Appalachian forests. Anim. Conserv. 2008, 11, 369-376.

112. Hyde, E.J.; Simons, T.R. Sampling plethodontid salamanders: Sources of variability. J. Wildl. Manag. 2001, 65, 624-632.

113. Chapin, F.S., III; Zavaleta, E.S.; Eviner, V.T.; Naylor, R.L.; Vitousek, P.M.; Reynolds, H.L.; Hooper, D.U.; Lavorel, S.; Sala, O.E.; Hobbie, S.E.; et al. Consequences of changing biodiversity. Nature 2000, 405, 234-242.

114. Stuart, S.N.; Chanson, J.S.; Cox, N.A.; Young, B.E.; Rodrigues, A.S.L.; Fischman, D.L.; Waller, R.W. Status and trends of amphibian declines and extinctions worldwide. Science 2004, 306, 1783-1786.

115. Lowe, W.H.; Likens, G.E. Moving headwater streams to the head of the class. BioScience 2005, 55, 196-197.

116. Freeman, M.C.; Pringle, C.M.; Jackson, C.R. Hydrologic connectivity and the contribution of stream headwaters to ecological integrity at regional scales. J. Am. Water Res. Assoc. 2007, 43, 5-14.

117. Lowe, W.H. Landscape-scale spatial population dynamics in human-impacted stream systems. Environ. Manag. 2002, 30, 225-233.

118. DeMaynadier, P.G.; Hunter, M.L., Jr. The relationship between forest management and amphibian ecology: A review of the North American literature. Environ. Rev. 1995, 3, 230-261.

119. Grialou, J.A.; West, S.D.; Wilkins, R.N. The effects of forest clearcut harvesting and thinning on terrestrial salamanders. J. Wildl. Manag. 2000, 64, 105-113. 
120. Knapp, S.M.; Haas, C.A.; Harpole, D.N.; Kirkpatrick, R.L. Initial effects of clearcutting and alternative silvicultural practices on terrestrial salamander abundance. Conserv. Biol. 2003, 17, 752-762.

121. Petranka, J.W.; Eldridge, M.E.; Haley, K.E. Effects of timber harvesting on southern Appalachian salamanders. Conserv. Biol. 1993, 7, 363-370.

122. Johnston, B.; Frid, L. Clearcut logging restricts the movements of terrestrial Pacific giant salamanders (Dicamptodon tenebrosus Good). Can. J. Zool. 2002, 80, 2170-2177.

123. Harpole, D.N.; Haas, C.A. Effects of seven silvicultural treatments on terrestrial salamanders. For. Ecol. Manag. 1999, 114, 349-356.

124. Homyack, J.A.; Haas, C.A. Long-term effects of experimental forest harvesting on abundance and reproductive demography of terrestrial salamanders. Biol. Conserv. 2009, 142, 110-121.

125. Perkins, D.W.; Hunter, M.L., Jr. Effects of riparian timber management on amphibians in Maine. J. Wildl. Manag. 2006, 70, 657-670.

126. Patrick, D.A.; Hunter, M.L., Jr.; Calhoun, A.J.K. Effects of experimental forestry treatments on a Maine amphibian community. For. Ecol. Manag. 2006, 234, 323-332.

127. Fredericksen, T.S.; Ross, B.D.; Hoffman, W.; Ross, E.; Morrison, M.L.; Beyea, J.; Lester, M.B.; Johnson, B.N. The impact of logging on wildlife: A study in northeastern Pennsylvania. J. For. 2000, 98, 4-10.

128. Ford, W.M.; Menzel, M.A.; Odom, R.H. Elevation, aspect, and cove size effects on southern Appalachian salamanders. Southeast. Nat. 2002, 1, 315-324.

129. Steele, C.A.; Brodie, E.D., Jr.; MacCracken, J.G. Influence of forest age on densities of Cope's and Pacific giant salamanders. Northwest Sci. 2002, 76, 347-352.

130. Steele, C.A.; Brodie, E.D., Jr.; MacCracken, J.G. Relationships between abundance of cascade torrent salamanders and forest age. J. Wildl. Manag. 2003, 67, 447-453.

131. Dupuis, L.A.; Smith, J.N.M.; Bunnell, F. Relation of terrestrial-breeding amphibian abundance to tree-stand age. Conserv. Biol. 1995, 9, 645-653.

132. Semlitsch, R.D.; Todd, B.D.; Blomquist, S.M.; Calhoun, A.J.; Gibbons, J.W.; Gibbs, J.P.; Graeter, G.J.; Harper, E.B.; Hocking, D.J.; Hunter, M.L., Jr.; et al. Effects of timber harvest on amphibian populations: Understanding mechanisms from forest experiments. Bioscience 2009, 59, 853-862.

133. Minshall, G.W.; Robinson, C.T.; Lawrence, D.E. Postfire responses of lotic ecosystems in Yellowstone National Park, USA. Can. J. Fish. Aq. Sci. 1997, 54, 2509-2525.

134. Russell, K.R.; van Lear, D.H.; Guynn, D.C., Jr. Prescribed fire effects on herpetofauna: Review and management implications. Wildl. Soc. Bull. 1999, 27, 374-384.

135. Bury, R.B.; Major, D.J.; Pilliod, D. Responses of amphibians to fire disturbance in Pacific Northwest forests: A review. In The Role of Fire in Nongame Wildlife Management and Community Restoration: Traditional Uses and New Directions Proceedings of a Special Workshop; General Technical Report NE-288; Ford, W.M., Russell, K.R., Moorman, C.E., Eds.; USA Department of Agriculture, Forest Service, Northeast Research Station: Nashville, TN, USA, 2000; pp. 39-42.

136. Schurbon, J.M.; Fauth, J.E. Effects of prescribed burning on amphibian diversity in a southeastern U.S. national forest. Conserv. Biol. 2003, 17, 1338-1349. 
137. Kerby, J.L.; Kats, L.B. Modified interactions between salamander life stages caused by wildfire-induced sedimentation. Ecology 1998, 79, 740-745.

138. Mushinsky, H.R. Fire and the Florida sandhill herpetofaunal community: With special attention to responses of Cnemidophorus sexlineatus. Herpetologica 1985, 41, 333-342.

139. Ford, W.M.; Menzel, M.A.; McGill, D.W.; Laerm, J.; McCay, T.S. Effects of a community restoration fire on small mammals and herpetofauna in the southern Appalachians. For. Ecol. Manag. 1999, 114, 233-243.

140. Vreeland, J.K.; Tietje, W.D. Numerical responses of small vertebrates to prescribed fire in California oak woodland. In The Role of Fire in Nongame Wildlife Management and Community Restoration: Traditional Uses and New Directions; Ford, W.M., Russell, K.R., Moorman, C.E., Eds.; General Technical Report NE-288; USA Department of Agriculture, Forest Service, Northeast Research Station: Nashville, TN, USA, 2000; pp. 91-99.

141. Riley, S.P.; Busteed, G.T.; Kats, L.B.; Vandergon, T.L.; Lee, L.F.S.; Dagit, R.G.; Kerby, J.L.; Fisher, R.N.; Sauvajot, R.M. Effects of urbanization on the distribution and abundance of amphibians and invasive species in southern California streams. Conserv. Biol. 2005, 19, 1894-1907.

142. Scheffers, B.R.; Paszkowski, C.A. The effects of urbanization on North American amphibian species: Identifying new directions for urban conservation. Urban Ecosyst. 2012, 15, 133-147.

143. Orser, P.N.; Shure, D.J. Effects of urbanization on the salamander Desmognathus fuscus fuscus. Ecology 1972, 53, 1148-1154.

144. Price, S.J.; Dorcas, M.E.; Gallant, A.L.; Klaver, R.W.; Willson, J.D. Three decades of urbanization: Estimating the impact of land-cover change on stream salamander populations. Biol. Conserv. 2006, 133, 436-441.

145. Price, S.J.; Cecala, K.K.; Browne, R.A.; Dorcas, M.E. Effects of urbanization on occupancy of stream salamanders. Conserv. Biol. 2011, 25, 547-555.

146. Price, S.J.; Browne, R.A.; Dorcas, M.E. Evaluating the effects of urbanisation on salamander abundances using a before-after control-impact design. Freshw. Biol. 2012, 57, 193-203.

147. Gibbs, J.P. Amphibian movements in response to forest edges, roads, and streambeds in southern New England. J. Wildl. Manag. 1998, 62, 584-589.

148. Gibbs, J.P. Distribution of woodland amphibians along a forest fragmentation gradient. Landsc. Ecol. 1998, 13, 263-268.

149. Fahrig, L.; Pedlar, J.H; Pope, S.E.; Taylor, P.D.; Wegner, J.F. Effect of road traffic on amphibian density. Biol. Conserv. 1995, 73, 177-182.

150. Carr, L.W.; Fahrig, L. Effect of road traffic on two amphibian species of differing vagility. Conserv. Biol. 2001, 15, 1071-1078.

151. Hels, T.; Buchwald, E. The effect of road kills on amphibian populations. Biol. Conserv. 2001, 99, 331-340.

152. Semlitsch, R.D.; Ryan, T.J.; Hamed, K.; Chatfield, M.; Drehman, B.; Pekarek, N.; Spath, M.; Watland, A. Salamander abundance along road edges and within abandoned logging roads in Appalachian forests. Conserv. Biol. 2007, 21, 159-167.

153. Ward, R.L.; Anderson, J.T.; Petty, J.T. Effects of road crossings on stream and streamside salamanders. J. Wildl. Manag. 2008, 72, 760-771. 
154. Anderson, J.T.; Ward, R.L.; Petty, J.T.; Kite, J.S.; Strager, M.P. Culvert effects on stream and stream-side salamander habitats. Int. J. Environ. Sci. Dev. 2014, 5, 274-281.

155. Cushman, S.A. Effects of habitat loss and fragmentation on amphibians: A review and prospectus. Biol. Conserv. 2006, 128, 231-240.

156. Olson, D.H.; Burnett, K.M. Design and management of linkage areas across headwater drainages to conserve biodiversity in forest ecosystems. For. Ecol. Manag. 2009, 258, S117-S126.

157. Anderson, J.T.; Solis, A.B.; Osbourne, J.D. Herpetofaunal abundance in forested edge and interior locations of West Virginia. In Proceedings of the 18th Central Hardwoods Forest Conference, Morgantown, WV, USA, 26-28 March 2012; pp. 474-486.

158. DeMaynadier, P.G.; Hunter, M.L., Jr. Effects of silvicultural edges on the distribution and abundance of amphibians in Maine. Conserv. Biol. 1998, 12, 340-352.

159. Vallan, D. Influence of forest fragmentation on amphibian diversity in the nature reserve of Ambohitantely, highland Madagascar. Biol. Conserv. 2000, 96, 31-43.

160. Gibbs, J.P. Genetic structure of redback salamander Plethodon cinereus populations in continuous and fragmented forests. Biol. Conserv. 1998, 86, 77-81.

161. Becker, C.G.; Fonseca, C.R.; Haddad, C.F.B.; Batista, R.F.; Prado, P.I. Habitat split and the global decline of amphibians. Science 2007, 318, 1775-1777.

162. Dillard, L.O.; Russell, K.R.; Ford, W.M. Site-level habitat models for the endemic, threatened Cheat Mountain salamander (Plethodon nettingi): The importance of geophysical and biotic attributes for predicting occurrence. Biodivers. Conserv. 2008, 17, 1475-1492.

(C) 2014 by the authors; licensee MDPI, Basel, Switzerland. This article is an open access article distributed under the terms and conditions of the Creative Commons Attribution license (http://creativecommons.org/licenses/by/4.0/). 